\title{
ANALISIS PERILAKU PEMBELIAN BUAH DI PERDESAAN DAN PERKOTAAN
}

\author{
Retnaningsih $\left.^{1^{\star}}\right)$, Rahmi Parhati ${ }^{1}$, Megawati Simanjuntak $^{1}$ \\ ${ }^{1}$ Departemen IImu Keluarga dan Konsumen, Fakultas Ekologi Manusia, Institut Pertanian Bogor, \\ Bogor 16680, Indonesia \\ *)E-mail: lunafisa@yahoo.com
}

\begin{abstract}
Abstrak
Penelitian ini bertujuan untuk menganalisis perbedaan perilaku pembelian buah di wilayah perdesaan dan perkotaan. Selain itu, penelitian ini juga bertujuan untuk menganalisis pengaruh karakteristik keluarga dan pengetahuan terhadap perilaku pembelian buah. Penelitian dilakukan di Kelurahan Panaragan (Kota Bogor) dan Desa Cihideung Ilir (Kabupaten Bogor) dengan jumlah responden adalah 99 ibu rumah tangga yang dipilih secara acak. Data dikumpulkan melalui wawancara dan dianalisis menggunakan analisis deskriptif, uji beda, dan uji regresi. Hasil penelitian menunjukkan bahwa ibu rumah tangga di wilayah perdesaan memiliki pengetahuan dan perilaku pembelian yang berbeda signifikan dibandingkan dengan ibu rumah tangga di perkotaan. Perilaku pembelian buah berdasarkan jenis buah, asal buah, frekuensi pembelian, dan jumlah pembelian buah dipengaruhi oleh usia dan lama pendidikan. Selain itu, pendapatan dan pengetahuan juga berpengaruh terhadap perilaku pembelian buah responden berdasarkan asal buah.
\end{abstract}

Kata kunci: buah, desa, kota, perilaku pembelian

\section{Analysis of Purchasing Behavior of Fruit in Rural and Urban Areas}

\begin{abstract}
This study aimed to analyze the differences of purchasing behavior of fruit in rural and urban areas. In addition, this study also aimed to analyze the influence of family characteristics and knowledge on the purchasing behavior of the fruit. The study was conducted in the Panaragan Village (Bogor City) and Cinideung llir village (Bogor Regency) and involved a number of respondents that were 99 housewives that were selected randomly. Data were collected by interviews and analyzed by descriptive analysis, different test, and regression test. The results showed that the housewives of rural areas had the knowledge and purchasing behavior that were significantly different than in the urban's housewives. Purchasing behavior based on the type of fruit, fruit origin, frequency of purchase, and the purchase amount of fruit were affected by age and length of education. In addition, income and knowledge also influenced the purchasing behavior of fruit housewives based on the origin of the fruit.
\end{abstract}

Keywords: fruits, purchasing behavior, rural, urban

\section{PENDAHULUAN}

Berdasarkan Sensus Penduduk 2010, jumlah penduduk Indonesia sudah mencapai 237,6 juta jiwa atau bertambah 32,5 juta jiwa sejak tahun 2000 . Artinya, setiap tahun selama periode 1990-2000, jumlah penduduk meningkat 3,25 juta jiwa (BPS, 2010). Peningkatan jumlah penduduk mengakibatkan semakin meningkatnya konsumsi pangan masyarakat di Indonesia. Menurut Hardinsyah, et al. (2002), tidak ada satu jenis pangan yang dapat memenuhi zat gizi kecuali ASI. Dengan demikian, untuk memenuhi kebutuhan zat gizi tersebut, harus ada asupan gizi yang seimbang tidak hanya oleh satu jenis bahan makanan, melainkan harus terdiri atas aneka ragam makanan yang salah satunya adalah dengan mengonsumsi buah yang merupakan sumber vitamin. Sebelum manusia mengonsumsi suatu produk, untuk dapat memperoleh produk tersebut maka manusia melakukan perilaku pembelian terlebih dahulu.

Keputusan untuk membeli buah dalam rumah tangga biasanya diambil oleh isteri. Isteri (ibu rumah tangga) biasanya menjadi orang yang paling menentukan dalam pengambilan keputusan pembelian. Oleh sebab itu, isteri perlu memiliki pengetahuan yang baik dan menguasai berbagai keterampilan. Pendidikan isteri, disamping merupakan modal utama dalam menunjang perekonomian rumah tangga juga berperan dalam pola penyusunan makanan untuk rumah tangga. 
Perilaku pembelian buah merupakan salah satu bentuk perilaku konsumen. Menurut Kotler (2002), faktor-faktor utama yang memengaruhi perilaku konsumen antara lain adalah faktor budaya, sosial, pribadi, dan psikologis. Budaya merupakan salah satu penentu keinginan dan perilaku seseorang yang paling mendasar dan sesungguhnya seluruh masyarakat memiliki stratifikasi sosial dimana kelas sosial menunjukkan pilihan terhadap produk dengan merek yang berbeda-beda. Perilaku pembelian juga dipengaruhi oleh karakteristik, seperti umur, pekerjaan, dan keadaan ekonomi. Pilihan membeli seseorang juga akan dipengaruhi faktor psikologis seperti motivasi.

Menurut hasil survei BPS (2009), konsumsi buah di Indonesia masih rendah, yaitu sebesar 60,4 persen masyarakat Indonesia hanya mengonsumsi satu porsi buah atau bahkan kurang dalam satu hari. Selain itu, konsumsi buah-buahan di Indonesia hanya $40,1 \mathrm{~kg} / \mathrm{kap} / \mathrm{th}$, masih cukup jauh dari rekomendasi Organisasi Pangan Dunia (FAO) yaitu $65,7 \mathrm{~kg}$ per kapita per tahun. Penyebab kematian sekitar 2,7 juta warga dunia setiap tahunnya disebabkan tidak cukupnya makan sayur-sayuran dan buah-buahan. Rendahnya konsumsi kedua sumber serat tersebut menjadikannya masuk ke dalam 10 besar faktor penyebab kematian di dunia.

Oleh karenanya, adanya produk dan pengetahuan tentang buah serta kebiasaan yang berbeda pada masyarakat di perdesaan dan perkotaan maka penelitian ini bertujuan untuk menganalisis perbedaan perilaku pembelian buah di wilayah perdesaan dan perkotaan. Selain itu, penelitian ini juga bertujuan untuk menganalisis variabel-variabel yang berpengaruh terhadap perilaku pembelian buah.

\section{METODE}

Disain penelitian ini adalah cross sectional. Lokasi penelitian dipilih secara purposive yaitu di Kelurahan Panaragan, Kota Bogor (wilayah perkotaan) dan Desa Cihideung Ilir, Kabupaten Bogor (wilayah perdesaan). Pengambilan data penelitian dilakukan pada bulan Mei sampai dengan bulan Juni 2010.

Responden dalam penelitian ini adalah 50 ibu rumah tangga di Kelurahan Panaragan, Kota Bogor dan 49 ibu rumah tangga di Desa Cihideung Ilir, Kabupaten Bogor. Jumlah responden ditentukan dengan menggunakan rumus Slovin dengan galat sebesar 0,10 .
Penarikan responden dilakukan secara acak sistematis.

Data primer dalam penelitian ini dikumpulkan melalui wawancara dengan menggunakan kuesioner terstruktur. Data tersebut terdiri atas karakteristik keluarga, pengetahuan isteri, dan perilaku pembelian buah. Karakteristik keluarga meliputi besar keluarga, usia suami dan isteri, pendidikan suami dan isteri, pekerjaan suami dan isteri, dan pendapatan keluarga. Besar keluarga diukur berdasarkan jumlah anggota keluarga dan dikategorikan menjadi keluarga kecil ( $\leq 4$ orang), sedang (5-6 orang), dan besar ( $\geq 7$ orang). Usia suami dan isteri dinyatakan dalam tahun dan dikategorikan berdasarkan Papalia, Olds, dan Feldman (2008) menjadi dewasa awal (18-40 tahun), dewasa madya (41-60 tahun), dan dewasa akhir (>60 tahun). Pendidikan suami dan isteri diukur berdasarkan tingkatnya dan dikategorikan menjadi tidak sekolah, tidak tamat $\mathrm{SD}$, tamat $\mathrm{SD}$, tamat SMP, tamat SMA, dan Diploma/Strata 1/Strata 2. Pekerjaan suami dan isteri dibedakan menjadi bekerja dan tidak bekerja. Pendapatan keluarga diukur berdasarkan pendapatan keluarga per kapita per bulan dan dikategorikan menjadi miskin, hampir miskin, hampir tidak miskin, dan tidak miskin berdasarkan garis kemiskinan Jawa Barat tahun 2009 yaitu Rp191.985,00. Data perilaku pembelian buah meliputi jenis dan asal buah, frekuensi dan jumlah pembelian buah, dan ketersediaan buah di tempat pembelian.

Data yang telah dikumpulkan diolah dan dianalisis. Analisis data yang digunakan adalah analisis deskriptif, uji beda, dan uji regresi. Uji beda dilakukan untuk menganalisis perbedaan perilaku pembelian buah antara keluarga yang tinggal di wilayah perdesaan dan perkotaan. Sementara itu, uji regresi dilakukan untuk menganalisis variabel-variabel yang memengaruhi perilaku pembelian buah di perdesaan dan perkotaan.

\section{HASIL}

\section{Karakteristik Keluarga}

Hasil penelitian menunjukkan bahwa persentase terbesar keluarga dalam penelitian ini baik keluarga yang tinggal di wilayah perdesaan $(62,0 \%)$ maupun keluarga yang tinggal di wilayah perkotaan $(70,0 \%)$ merupakan keluarga kecil dengan jumlah anggota keluarga empat orang. Besar keluarga responden yang tinggal di wilayah perdesaan dan perkotaan berbeda signifikan $(p<0,1)$. 
Persentase terbesar suami di wilayah perdesaan berusia dewasa madya $(50,0 \%)$, sedangkan suami di wilayah perkotaan berusia dewasa awal $(52,2 \%)$. Sementara itu, usia isteri baik di wilayah perdesaan $(58.0 \%)$ maupun di wilayah perkotaan $(60,0 \%)$ sebagian besar berusia dewasa awal.

Berdasarkan tingkat pendidikan, persentase terbesar suami $(50,0 \%)$ dan isteri $(58,0 \%)$ di wilayah perdesaan telah menamatkan pendidikan pada jenjang SD, sedangkan suami $(67,4 \%)$ dan isteri $(58,0 \%)$ di wilayah perkotaan telah menamatkan pendidikan pada jenjang SMA. Pendidikan suami dan isteri di wilayah perdesaan dan perkotaan berbeda signifikan $(p<0,01)$. Persentase terbesar suami di wilayah perdesaan $(32,6 \%)$ adalah bekerja dengan jenis pekerjaan adalah buruh. Suami di wilayah perkotaan $(47,8 \%)$ juga bekerja dengan jenis pekerjaan Pegawai Negeri Sipil (PNS). Sementara itu, isteri baik di wilayah perdesaan $(80,0 \%)$ dan perkotaan $(78,0 \%)$ bekerja sebagai ibu rumah tangga. Berdasarkan pendapatan keluarga, keluarga responden yang tinggal di wilayah perdesaan $(58,0 \%)$ dan perkotaan $(92,0 \%)$ termasuk dalam kategori tidak miskin.

\section{Pengetahuan Isteri tentang Buah}

Pengetahuan tentang buah merupakan informasi yang dimiliki oleh isteri mengenai buah. Hasil penelitian menunjukkan bahwa persentase terbesar isteri dalam penelitian ini baik isteri yang hidup di wilayah perdesaan $(70,0 \%)$ maupun isteri yang hidup di wilayah perkotaan $(92,0 \%)$ memiliki pengetahuan yang baik tentang buah. Hasil penelitian juga menunjukkan bahwa masih terdapat satu dari sepuluh isteri yang memiliki pengetahuan yang kurang baik tentang buah. Pengetahuan isteri tentang buah di wilayah perdesaan dan perkotaan berbeda signifikan $(p<0,01)$. Isteri yang tinggal di wilayah perkotaan mempunyai pengetahuan tentang buah yang lebih baik daripada isteri yang tinggal di wilayah perdesaan.

\section{Perilaku Pembelian Buah}

Perilaku pembelian merupakan fungsi dari niat pembelian dan pengaruh lingkungan atau perbedaan individu (Engel, Blackwell, \& Miniard, 1994). Pembelian meliputi keputusan konsumen mengenai apa yang dibeli, apakah membeli atau tidak, kapan membeli, dimana membeli, dan bagaimana cara pembayarannya. Kebiasaan pembelian buah setiap rumah tangga hampir berbeda-beda. Hal ini bergantung pada kebutuhan akan buah, ketersediaan buah, pendapatan yang diperoleh, dan kebiasaan mengonsumsi buah. Jika dilihat dari tipe pembelian, perilaku pembelian buah yang dilakukan konsumen termasuk kepada tipe perilaku pembelian kebiasaan, yaitu perilaku pembelian kebiasaan terjadi dalam keadaan keterlibatan konsumen yang rendah dan sedikit perbedaan merek.

Jenis dan Asal Buah. Hasil penelitian menunjukkan bahwa terdapat 22 jenis buah yang dibeli oleh isteri yang berada di wilayah perdesaan (Tabel 1). Tabel 1 menunjukkan bahwa sebagian besar responden di wilayah perdesaan mengonsumsi buah jeruk, salak, apel, semangka, melon, mangga, dan buah lainnya. Buah jeruk yang dikonsumsi berasal dari impor $(50,0 \%)$ dan lokal $(50,0 \%)$. Buah salak, semangka, mangga, dan melon yang dikonsumsi merupakan buah lokal. Sementara buah apel yang dikonsumsi merupakan buah impor $(52,4 \%)$ dan lokal $(47,6 \%)$.

Buah yang paling sedikit dibeli oleh responden di wilayah perdesaan adalah bengkuang, durian, alpukat, manggis, ketimun, nangka, dan jambu air. Buah yang dibeli oleh isteri di perdesaan dan di perkotaan sedikit berbeda, buah yang tidak dibeli oleh isteri di perdesaan akan tetapi dibeli oleh isteri di perkotaan adalah buah nanas, buah naga, sawo, belimbing, dan buah sirsak.

Hasil penelitian juga menunjukkan bahwa terdapat 25 jenis buah yang dibeli oleh isteri yang berada di wilayah perkotaan. Jenis buah yang paling banyak dibeli oleh isteri adalah buah jeruk impor $(70,2 \%)$. Jenis buah kedua yang banyak dibeli responden adalah buah apel impor $(67,7 \%)$ dan buah pisang lokal $(87,1 \%)$. Persentase tertinggi ketiga adalah buah mangga lokal $(100,0 \%)$. Selain itu, responden di perkotaan melakukan perilaku pembelian buah pepaya, rambutan, dan salak yang merupakan buah lokal.

Buah yang paling sedikit dibeli oleh isteri di wilayah perkotaan adalah buah nangka, ketimun, buah naga, jambu air, dan nanas. Buah yang tidak dibeli oleh yang tinggal di wilayah perkotaan akan tetapi dibeli oleh isteri yang tinggal di wilayah perdesaan adalah buah duku dan bengkuang. Hasil uji beda juga menunjukkan bahwa terdapat perbedaan $(p<0,01)$ yang signifikan antara keberagaman jenis buah yang dibeli oleh isteri yang tinggal di wilayah perdesaan dan perkotaan (Tabel 1). 
Tabel 1 Sebaran keluarga di wilayah perdesaan dan perkotaan berdasarkan perilaku pembelian yang dilihat dari jenis dan asal buah

\begin{tabular}{|c|c|c|c|c|c|c|c|}
\hline \multirow{2}{*}{ No } & \multirow{2}{*}{ Jenis Buah } & \multicolumn{3}{|c|}{ Wilayah Perdesaan } & \multicolumn{3}{|c|}{ Wilayah Perkotaan } \\
\hline & & Jumlah (\%) & Buah impor & Buah lokal & Jumlah (\%) & Buah impor & Buah lokal \\
\hline 1 & Jeruk & 98,0 & 50,0 & 50,0 & 94,0 & 70,2 & 29,8 \\
\hline 2 & Apel & 42,9 & 52,4 & 47,6 & 62,0 & 67,7 & 32,3 \\
\hline 3 & Pisang & 22,4 & 0,0 & 100,0 & 62,0 & 12,9 & 87,1 \\
\hline 4 & Mangga & 28,6 & 0,0 & 100,0 & 60,0 & 0,0 & 100,0 \\
\hline 5 & Pepaya & 22,4 & 0,0 & 100,0 & 36,0 & 0,0 & 100,0 \\
\hline 6 & Pir & 10,2 & 0,0 & 0,0 & 34,0 & 100,0 & 0,0 \\
\hline 7 & Rambutan & 22,4 & 0,0 & 100,0 & 34,0 & 0,0 & 100,0 \\
\hline 8 & Semangka & 30,6 & 0,0 & 100,0 & 28,0 & 0,0 & 100,0 \\
\hline 9 & Salak & 61,2 & 0,0 & 100,0 & 26,0 & 0,0 & 100,0 \\
\hline 10 & Melon & 28,6 & 0,0 & 100,0 & 18,0 & 0,0 & 0,0 \\
\hline 11 & Kelengkeng & 12,2 & 16,7 & 83,3 & 4,0 & 0,0 & 100,0 \\
\hline 12 & Anggur & 14,3 & 42,8 & 57,2 & 14,0 & 71,4 & 28,6 \\
\hline 13 & Jambu biji & 12,2 & 0,0 & 100,0 & 10,0 & 0,0 & 100,0 \\
\hline 14 & Tomat & 6,1 & 0,0 & 100,0 & 6,0 & 0,0 & 100,0 \\
\hline 15 & Durian & 2,0 & 100,0 & 0,0 & 12,0 & 83,3 & 16,7 \\
\hline 16 & Alpukat & 2,0 & 0,0 & 100,0 & 14,0 & 0,0 & 100,0 \\
\hline 17 & Duku & 2,0 & 80,0 & 20,0 & 0,0 & 0,0 & 0,0 \\
\hline 18 & Manggis & 2,0 & 0,0 & 100,0 & 4,0 & 0,0 & 100,0 \\
\hline 19 & Bengkuang & 2,0 & 0,0 & 100,0 & 0,0 & 0,0 & 0,0 \\
\hline 20 & Ketimun & 2,0 & 0,0 & 100,0 & 2,0 & 0,0 & 100,0 \\
\hline 21 & Nangka & 2,0 & 0,0 & 100,0 & 2,0 & 0,0 & 100,0 \\
\hline 22 & Jambu air & 2,0 & 0,0 & 100,0 & 2,0 & 0,0 & 100,0 \\
\hline 23 & Nanas & 0,0 & 0,0 & 0,0 & 2,0 & 0,0 & 100,0 \\
\hline 24 & Buah naga & 0,0 & 0,0 & 0,0 & 2,0 & 0,0 & 100,0 \\
\hline 25 & Sawo & 0,0 & 0,0 & 0,0 & 4,0 & 0,0 & 100,0 \\
\hline 26 & Belimbing & 0,0 & 0,0 & 0,0 & 6,0 & 0,0 & 100,0 \\
\hline \multirow[t]{2}{*}{27} & Sirsak & 0,0 & 0,0 & 0,0 & 4,0 & 0,0 & 100,0 \\
\hline & $p$-value & \multicolumn{6}{|c|}{$0,002^{\star * *}$} \\
\hline
\end{tabular}

Keterangan: ${ }^{* * *}$ Signifikan pada $p<0,01$

Frekuensi dan jumlah pembelian buah.

Perilaku pembelian yang dilihat dari frekuensi pembelian buah dan jumlah buah yang dibeli disajikan pada Tabel 2. Tabel 2 menunjukkan bahwa jenis buah yang paling banyak dibeli isteri yang berada di wilayah perdesaan adalah buah jeruk dengan frekuensi pembelian empat kali per bulan dengan jumlah pembelian 382,3 gram/kapita/bulan. Jenis buah kedua yang banyak dibeli isteri adalah buah salak dengan frekuensi satu kali per bulan dengan jumlah $390,8 \mathrm{gram} / \mathrm{kapita} / \mathrm{bulan}$. Buah apel dibeli isteri dengan frekuensi empat kali/ bulan dengan jumlah 365,9 gram/kapita/bulan.

Isteri juga melakukan perilaku pembelian terhadap buah semangka dengan frekuensi empat kali per bulan dengan jumlah pembelian $946,7 \mathrm{gram} / \mathrm{kapita} / \mathrm{bulan}$. Buah melon dan rambutan dibeli isteri dengan frekuensi empat kali per bulan dengan jumlah 1019,0 gram/ kapita/bulan untuk buah melon dan 866,7 gram/kapita/bulan untuk buah rambutan. Jenis buah yang jarang dibeli isteri adalah buah pir dengan frekuensi $0,3 \mathrm{kali} / \mathrm{bulan}$, buah durian dengan frekuensi $0,5 \mathrm{kali} / \mathrm{bulan}$, dan buah manggis dengan frekuensi $0,1 \mathrm{kali} / \mathrm{bulan}$.
Jenis buah paling banyak dibeli isteri yang berada di perkotaan adalah buah jeruk dengan frekuensi pembelian empat kali/bulan dengan jumlah pembelian sebanyak 562,6 gram/ kapita/bulan. Rata-rata kedua yang banyak dibeli isteri adalah buah apel dan pisang dengan frekuensi empat kali per bulan dengan jumlah 483,9 gram/kapita/bulan untuk buah apel dan 1226,9 gram/kapita/bulan untuk buah pisang. Buah mangga dibeli isteri yang berada di wilayah perkotaan dengan frekuensi empat kali/bulan dengan jumlah 716 gram/kapita/ bulan.

Selain keempat buah tersebut, isteri juga melakukan perilaku pembelian terhadap buah pir dan rambutan dengan frekuensi empat kali per bulan dengan jumlah pembelian 737,3 gram/kapita/bulan untuk buah pir dan 479,5 gram/kapita/bulan untuk buah rambutan. Buah yang paling jarang dibeli oleh isteri di wilayah perkotaan adalah buah alpukat dengan frekuensi 0,1 kali per bulan. Hasil uji beda juga menunjukkan bahwa terdapat perbedaan yang signifikan $(p<0,05)$ antara jumlah jenis buah yang dibeli oleh isteri yang tinggal di wilayah perdesaan dan perkotaan (Tabel 2). 
Tabel 2 Perilaku pembelian buah keluarga yang tinggal di wilayah perdesaan dan perkotaan berdasarkan frekuensi dan jumlah buah yang dibeli

\begin{tabular}{|c|c|c|c|c|c|}
\hline \multirow[b]{2}{*}{ No } & \multirow[b]{2}{*}{ Jenis Buah } & \multicolumn{2}{|c|}{ Wilayah Perdesaan } & \multicolumn{2}{|c|}{ Wilayah Perkotaan } \\
\hline & & $\begin{array}{c}\text { Frekuensi } \\
\text { (kali/bulan/kapita) }\end{array}$ & $\begin{array}{c}\text { Jumlah } \\
\text { (gram/kapita/bulan) }\end{array}$ & $\begin{array}{c}\text { Frekuensi } \\
\text { (kali/bulan/kapita) }\end{array}$ & $\begin{array}{c}\text { Jumlah } \\
\text { (gram/kapita/bulan) }\end{array}$ \\
\hline 1 & Jeruk & 4,0 & 382,3 & 4,0 & 562,6 \\
\hline 2 & Apel & 4,0 & 365,9 & 4,0 & 483,9 \\
\hline 3 & Pisang & 4,0 & 757,6 & 4,0 & 1226,9 \\
\hline 4 & Mangga & 1,0 & 571,4 & 4,0 & 716 \\
\hline 5 & Pepaya & 10,0 & 757,6 & 4,0 & 975,3 \\
\hline 6 & Pir & 0,3 & 400 & 4,0 & 479,5 \\
\hline 7 & Rambutan & 4,0 & 866,7 & 4,0 & 737,3 \\
\hline 8 & Semangka & 4,0 & 946,7 & 3,0 & 2579,4 \\
\hline 9 & Salak & 1,0 & 390,8 & 1,0 & 109,0 \\
\hline 10 & Melon & 4,0 & 1019,0 & 0,0 & 222,2 \\
\hline 11 & Kelengkeng & 1,0 & 333,3 & 1,0 & 83,3 \\
\hline 12 & Anggur & 1,0 & 261,9 & 4,0 & 71,4 \\
\hline 13 & Jambu biji & 1,0 & 194,4 & 1,0 & 755,6 \\
\hline 14 & Tomat & 30,0 & 111,1 & 30,0 & 468,9 \\
\hline 15 & Durian & 0,5 & 1000 & 4,0 & 2000 \\
\hline 16 & Alpukat & 4,0 & 666,7 & 0,1 & 301,6 \\
\hline 17 & Duku & 4,0 & 333,3 & 0,0 & 0,0 \\
\hline 18 & Manggis & 0,1 & 333,3 & 4,0 & 11,1 \\
\hline 19 & Bengkuang & 4,0 & 54,7 & 0,0 & 0,0 \\
\hline 20 & Ketimun & 30,0 & 333,3 & 1,0 & 1893,3 \\
\hline 21 & Nangka & 2,0 & 1333,3 & 1,0 & 55,6 \\
\hline 22 & Jambu air & 1,0 & 333,3 & 4,0 & 444,4 \\
\hline 23 & Nanas & 0,0 & 0,0 & 1,0 & 100 \\
\hline 24 & Buah naga & 0,0 & 0,0 & 1,0 & 222,2 \\
\hline 25 & Sawo & 0,0 & 0,0 & 1,0 & 111,1 \\
\hline 26 & Belimbing & 0,0 & 0,0 & 1,0 & 37,0 \\
\hline 27 & Sirsak & 0,0 & 0,0 & 1,0 & 111,1 \\
\hline & $p$-value & & & & $0,013^{* *}$ \\
\hline
\end{tabular}

Keterangan: ${ }^{* *}$ Signifikan pada $p<0,05$

Ketersediaan buah di tempat pembelian. Pada daerah penelitian terdapat pasar yang menyediakan buah secara lengkap dan letak pasar yang relatif dekat dengan pemukiman penduduk. Isteri yang tinggal di wilayah perdesaan $(83,7 \%)$ dan perkotaan $(68,0 \%)$ merasa buah selalu tersedia di tempat penjualan buah yang sering mereka kunjungi.

Produk atau barang yang dipajang di tempat penjualan bisa berfungsi sebagai rangsangan yang menarik konsumen untuk melihat dan membeli produk tersebut. Produk yang habis atau tidak tersedia di tempat penjualan akan mendorong konsumen mencari produk atau barang lain. Konsumen biasanya akan tertarik untuk datang ke toko atau tempat penjualan yang barang dagangannya beragam karena menyediakan banyak pilihan. Jika konsumen tidak menemukan barang yang dicari maka ada beberapa tindakan yang dilakukan seperti membeli barang lain di tempat yang sama, mencari ke tempat lain, atau tidak jadi membeli. Tindakan ini juga dilakukan konsumen ketika tidak menemukan buah yang ingin mereka beli.
Hasil penelitian menunjukkan bahwa jika buah tidak tersedia di tempat responden biasa membeli maka isteri baik yang tinggal di wilayah perdesaan $(40,8 \%)$ maupun di perkotaan $(38,0 \%)$ memilih untuk tidak jadi membeli buah. Selain itu, jika buah tidak tersedia maka isteri yang tinggal di wilayah perdesaan $(36,7 \%)$ dan perkotaan $(38,0 \%)$ juga ada yang memilih untuk mencari ke tempat pembelian buah yang lain. Adapun jika isteri ingin membeli buah akan tetapi buah yang diinginkan tidak tersedia di tempat yang biasa dibeli maka ada juga isteri yang tinggal di wilayah perdesaan $(22,5 \%)$ dan perkotaan $(24,0 \%)$ memilih untuk membeli buah dengan jenis lain (di tempat yang sama). Ketika konsumen menginginkan merek produk tertentu tetapi produk itu tidak tersedia maka pada saat itu konsumen akan memutuskan untuk membeli produk lain atau menunda pembeliannya, bergantung pada derajat kepentingan yang ada pada dirinya. Jika misalnya pada saat itu sangat membutuhkan produk itu, sementara merek yang diinginkan tidak tersedia dan hanya ada merek lain maka konsumen akan beralih ke merek yang tersedia di tempat penjualan. 
Isteri dalam penelitian ini membeli buah di berbagai tempat, diantaranya adalah pasar, supermarket, kios buah, penjual buah keliling, dan lain-lain. Hasil penelitian menunjukkan bahwa persentase terbesar isteri di wilayah perdesaan $(45,4 \%)$ membeli buah di pasar, sedangkan isteri di wilayah perkotaan $(45,4 \%)$ membeli buah di supermarket (Tabel 3 ). Persentase terbesar kedua untuk tempat pembelian buah oleh isteri yang tinggal di wilayah perdesaan adalah kios buah $(27,1 \%)$ dengan alasan dekat dengan tempat tinggal, sedangkan isteri di wilayah perkotaan persentase terbesar kedua adalah di pasar $(37,9 \%)$.

Alasan pemilihan tempat pembelian diantaranya adalah tempat yang strategis, kedekatan lokasi, serta kualitas dari produk yang diperjualbelikan. Hal-hal tersebut dapat memengaruhi keputusan konsumen untuk membeli suatu produk. Perilaku pembelian juga terkait dengan tempat pembelian. Isteri yang terlibat dalam penelitian ini juga mengemukakan beberapa alasan yang menjadi pertimbangan mereka dalam memilih tempat pembelian buah, contohnya adalah pasar dan supermarket. Pasar dipilih menjadi tempat yang sering dikunjungi oleh isteri yang tinggal di wilayah perdesaan untuk membeli buah karena letaknya yang dekat dengan tempat tinggal sehingga mudah dijangkau. Selian itu, harga buah yang dijual di pasar juga lebih murah dibandingkan dengan tempat lain. Isteri juga memilih supermarket sebagai tempat pembelian buah. Supermarket ini dipilih oleh isteri yang tinggal di wilayah perkotaan karena buah yang dijual di supermarket kualitasnya lebih bagus dibandingkan dengan tempat lain.

Tabel 3 Sebaran responden berdasarkan tempat pembelian buah

\begin{tabular}{|c|c|c|c|c|}
\hline \multirow[b]{2}{*}{ No } & \multirow{2}{*}{$\begin{array}{l}\text { Tempat } \\
\text { pembelian } \\
\text { buah }\end{array}$} & \multicolumn{2}{|c|}{ Wilayah } & \multirow[b]{2}{*}{ Total } \\
\hline & & Perdesaan & Perkotaan & \\
\hline 1 & Pasar & 45,4 & 37,9 & 83,3 \\
\hline 2 & Supermarket & 7,7 & 45,4 & 53,1 \\
\hline 3 & Kios buah & 27,1 & 1,5 & 28,6 \\
\hline 4 & $\begin{array}{l}\text { Penjual } \\
\text { buah keliling }\end{array}$ & 14,5 & 4,1 & 18,6 \\
\hline 5 & Mal & 0,0 & 10,0 & 10,0 \\
\hline 6 & Warung & 1,9 & 0,4 & 2,3 \\
\hline 7 & $\begin{array}{l}\text { Penjual } \\
\text { sayur }\end{array}$ & 1,4 & 0,0 & 1,4 \\
\hline 8 & Tetangga & 1,0 & 0,0 & 1,0 \\
\hline 9 & $\begin{array}{l}\text { Penjual } \\
\text { rujak }\end{array}$ & 0,0 & 0,7 & 0,7 \\
\hline 10 & $\begin{array}{l}\text { Pedagang } \\
\text { kaki lima }\end{array}$ & 0,5 & 0,0 & 0,5 \\
\hline 11 & Tengkulak & 0,5 & 0,0 & 0,5 \\
\hline
\end{tabular}

Pengaruh Karakteristik Keluarga dan Pengetahuan Isteri terhadap Perilaku Pembelian Buah

Perilaku pembelian berdasarkan keberagaman jenis buah yang dibeli dan asal buah. Model yang dibangun untuk menganalisis pengaruh karakteristik keluarga dan pengetahuan istri terhadap perilaku pembelian buah yang dilihat dari keberagaman jenis buah yang dibeli memiliki koefisien determinasi sebesar 0,193 (Tabel 4). Hasil ini memperlihatkan bahwa sebesar 19,3 persen keberagaman jenis buah yang dibeli dapat diterangkan oleh karakteristik keluarga dan sisanya 80,7 persen dijelaskan oleh variabel lain di luar model.

Hasil penelitian menunjukkan bahwa usia, lama pendidikan, dan pengetahuan isteri berpengaruh signifikan terhadap keberagaman jenis buah yang dibeli. Bertambahnya usia isteri dapat meningkatkan jumlah jenis buah yang dibeli. Demikian juga halnya dengan pendidikan isteri, bertambah tingginya pendidikan isteri menyebabkan peningkatan jenis buah yang dibeli. Keberagaman jenis buah yang dibeli responden juga dipengaruhi oleh pengetahuan isteri. Pengetahuan isteri yang semakin baik dapat mendorong isteri untuk membeli buah sehingga semakin banyak jenis buah yang dibeli.

Model yang dibangun untuk menganalisis pengaruh karakteristik keluarga dan pengetahuan isteri terhadap perilaku pembelian buah yang dilihat dari asal buah yang dibeli memiliki koefisien determinasi sebesar 0,081 (Tabel 4). Hasil ini memperlihatkan bahwa sebesar 8,1 persen perilaku pembelian yang dilihat dari asal buah dapat diterangkan oleh perubahan variabel bebas dalam model dan sisanya yaitu sebesar 92,9 persen dijelaskan oleh variabel lain yang tidak dianalisis dalam model ini.

Hasil analisis menunjukkan bahwa perilaku pembelian yang dilihat dari asal buah dipengaruhi oleh usia isteri $(\beta=0,201, p<0,10)$ dan pendidikan isteri $(\beta=0,282, \quad p<0,10)$. Bertambahnya usia isteri memengaruhi terjadinya peningkatan pembelian buah lokal. Demikian juga halnya dengan pendidikan isteri, bertambah tingginya jenjang pendidikan isteri maka menyebabkan kecenderungan untuk memilih buah lokal. 
Tabel 4 Koefisien regresi karakteristik keluarga dan pengetahuan isteri terhadap keberagaman jenis buah dan asal buah yang dibeli

\begin{tabular}{|c|c|c|c|c|}
\hline \multirow{2}{*}{$\begin{array}{c}\text { Variabel } \\
\text { Bebas }\end{array}$} & \multicolumn{2}{|c|}{ Jenis Buah } & \multicolumn{2}{|c|}{ Asal Buah } \\
\hline & Beta & Sig. & Beta & Sig. \\
\hline Konstanta & & 0,118 & & 0,206 \\
\hline $\begin{array}{l}\text { Lokasi } \\
\text { (1=perkotaan } \\
0=\text { perdesaan) }\end{array}$ & 0,087 & 0,534 & 0,156 & 0,299 \\
\hline $\begin{array}{l}\text { Besar } \\
\text { keluarga } \\
\text { (orang) }\end{array}$ & 0,114 & 0,296 & 0,042 & 0,718 \\
\hline $\begin{array}{l}\text { Usia isteri } \\
\text { (tahun) }\end{array}$ & 0,297 & $0,005^{* * *}$ & 0,201 & $0,074^{*}$ \\
\hline $\begin{array}{l}\text { Lama } \\
\text { pendidikan } \\
\text { isteri (tahun) }\end{array}$ & 0,457 & $0,003^{* * *}$ & 0,282 & $0,083^{*}$ \\
\hline $\begin{array}{l}\text { Pendapatan } \\
\text { keluarga }(R p)\end{array}$ & 0,024 & 0,834 & 0,228 & $0,069^{*}$ \\
\hline $\begin{array}{l}\text { Pekerjaan } \\
\text { isteri } \\
\text { (1=bekerja, } \\
0=\text { tidak } \\
\text { bekerja) }\end{array}$ & 0,051 & 0,581 & $0,00 \overline{2}^{-}$ & 0,985 \\
\hline $\begin{array}{l}\text { Pengetahuan } \\
\text { isteri (skor) }\end{array}$ & 0,191 & $0,065^{*}$ & 0,253 & $0,023^{* *}$ \\
\hline $\begin{array}{l}\text { Adjusted R } \\
\text { Square }\end{array}$ & & 0,193 & & 0,081 \\
\hline
\end{tabular}

Hasil penelitian yang disajikan pada Tabel 4 menunjukkan bahwa selain usia dan pendidikan isteri, perilaku pembelian buah yang dilihat dari asal buah juga dipengaruhi oleh pendapatan keluarga $(\beta=-0,228, \quad p<0,10)$. Bertambahnya pendapatan meningkatkan kecenderungan untuk membeli buah impor dan mengurangi pembelian buah lokal. Variabel lain yang memengaruhi perilaku pembelian yang dilihat dari asal buah adalah pengetahuan isteri $(\beta=0,253, p<0,05)$. Pengetahuan isteri yang semakin baik dapat mendorong isteri untuk membeli buah lokal.

Frekuensi dan jumlah pembelian buah. Pengaruh karakteristik keluarga dan pengetahuan isteri terhadap frekuensi dan jumlah pembelian buah dianalisis dengan menggunakan analisis regresi linear berganda. Model yang digunakan untuk menganalisis pengaruh karakteristik keluarga dan pengetahuan isteri terhadap perilaku pembelian yang dilihat dari frekuensi pembelian buah memiliki koefisien determinasi sebesar 0,124 (Tabel 5). Model ini menunjukkan bahwa sebesar 12,4 persen frekuensi pembelian buah dapat diterangkan oleh perubahan variabelvariabel bebas dalam model dan sisanya 87,6 persen dijelaskan oleh variabel lain di luar model. Variabel yang berpengaruh signifikan terhadap frekuensi pembelian buah adalah usia isteri $(\beta=0,333, \quad p<0,01)$. Usia isteri yang semakin bertambah dapat meningkatkan frekuensi pembelian buah dalam keluarga.

Model yang digunakan untuk menganalisis pengaruh karakteristik keluarga dan pengetahuan isteri terhadap perilaku pembelian yang dilihat dari jumlah pembelian buah memiliki koefisien determinasi sebesar 0,126. Model ini menunjukkan bahwa sebesar 12,6 persen perilaku pembelian yang dilihat dari jumlah buah yang dibeli dapat diterangkan oleh karakteristik keluarga dan pengetahuan isteri dan sisanya 87,4 persen dijelaskan oleh variabel lain di luar model. Variabel yang memengaruhi jumlah pembelian buah adalah besar keluarga $(\beta=0,208, p<0,1)$, usia isteri $(\beta=0,231, p<0,05)$, dan lama pendidikan isteri $(\beta=0,418, p<0,01)$. Peningkatan jumlah anggota keluarga menyebabkan bertambah banyaknya jumlah buah yang dibeli. Demikian juga halnya dengan usia isteri, penambahan usia isteri dapat meningkatkan jumlah buah yang dibeli. Selain itu, pendidikan isteri yang semakin lama juga mendorong isteri untuk membeli buah dalam jumlah yang banyak.

Tabel 5 Koefisien regresi karakteristik keluarga dan pengetahuan isteri terhadap frekuensi dan jumlah pembelian buah

\begin{tabular}{|c|c|c|c|c|}
\hline \multirow{2}{*}{$\begin{array}{c}\text { Variabel } \\
\text { Bebas }\end{array}$} & \multicolumn{2}{|c|}{ Frekuensi } & \multicolumn{2}{|c|}{ Jumlah Buah } \\
\hline & Beta & Sig. & Beta & Sig. \\
\hline Konstanta & & 0,808 & & 0,094 \\
\hline $\begin{array}{l}\text { Lokasi } \\
\text { (1=perkotaan } \\
0=\text { perdesaan) }\end{array}$ & 0,085 & 0,566 & $0,08 \overline{-}$ & 0,565 \\
\hline $\begin{array}{l}\text { Besar } \\
\text { keluarga } \\
\text { (orang) }\end{array}$ & $0,13 \overline{7}$ & 0,235 & 0,208 & $0,068^{*}$ \\
\hline Usia isteri (th) & 0,333 & $0,003^{* * *}$ & 0,231 & $0,036^{* *}$ \\
\hline $\begin{array}{l}\text { Lama } \\
\text { pendidikan } \\
\text { isteri (tahun) }\end{array}$ & 0,140 & 0,385 & 0,418 & $0,009^{* * *}$ \\
\hline $\begin{array}{l}\text { Pendapatan } \\
\text { keluarga (Rp) }\end{array}$ & $0,100^{-}$ & 0,422 & 0,008 & 0,945 \\
\hline $\begin{array}{l}\text { Pekerjaan } \\
\text { isteri }\end{array}$ & & & & \\
\hline $\begin{array}{l}\text { (1=bekerja, } \\
0=\text { tidak } \\
\text { bekerja) }\end{array}$ & 0,086 & 0,382 & 0,043 & 0,653 \\
\hline $\begin{array}{l}\text { Pengetahuan } \\
\text { isteri (skor) }\end{array}$ & $0,018^{-}$ & 0,865 & 0,130 & 0,227 \\
\hline $\begin{array}{l}\text { Adjusted } R \\
\text { Square }\end{array}$ & & 0,124 & & 0,126 \\
\hline
\end{tabular}

Keterangan:

* Signifikan pada $p<0,10$; ** Signifikan pada $p<0,05$;

*** Signifikan pada $p<0,01$ 


\section{PEMBAHASAN}

Perilaku pembelian buah dilihat dari keberagaman jenis buah yang dibeli, asal buah, frekuensi pembelian buah, dan jumlah buah yang dibeli. Secara umum, perilaku pembelian buah oleh isteri yang tinggal di wilayah perdesaan dan perkotaan dipengaruhi oleh karakteristik keluarga dan pengetahuan isteri tentang buah.

Perilaku pembelian buah yang dilihat dari keberagaman jenis buah dipengaruhi oleh usia isteri, lama pendidikan isteri, dan pengetahuan isteri. Usia isteri berpengaruh signifikan terhadap perilaku pembelian yang dilihat dari keragaman jenis buah yang dibeli. Hasil ini dapat diartikan bahwa pembelian buah semakin beragam dengan semakin bertambahnya usia isteri. Usia isteri tergolong dalam usia produktif dan membutuhkan asupan yang beragam dan berimbang. Hasil yang diperoleh ini sejalan dengan penelitian yang dilakukan oleh Prasatya (1998) yang menyatakan bahwa adanya perubahan-perubahan fisiologis pada tubuh seseorang menyebabkan pola konsumsi buahnya berbeda.

Lama pendidikan isteri berpengaruh signifikan positif terhadap perilaku pembelian yang dilihat dari keragaman jenis buah yang dibeli. Hasil ini mengindikasikan bahwa buah yang dibeli isteri semakin beragam dengan semakin lamanya pendidikan formal yang ditempuh oleh isteri. Pendidikan erat kaitannya dengan pengetahuan. Pendidikan yang tinggi dapat meningkatkan pengetahuan isteri tentang berbagai hal termasuk juga pengetahuan buah. Pengetahuan tentang buah yang baik ini juga dapat meningkatkan perilaku pembelian buah yang dilihat dari keberagaman buah yang dibeli. Penelitian ini juga menemukan bahwa pengetahuan isteri berpengaruh signifikan positif terhadap perilaku pembelian yang dilihat dari keragaman jenis buah yang dibeli. Dengan demikian, pendidikan dan pengetahuan isteri dapat meningkatkan keberagaman buah yang dibeli oleh isteri.

Perilaku pembelian juga dilihat dari aspek asal buah. Asal buah dalam penelitian ini dibedakan dalam dua kelompok yaitu lokal dan impor. Berdasarkan asal buah, perilaku pembelian dipengaruhi oleh usia isteri, lama pendidikan isteri, dan pendapatan keluarga. Hasil ini menunjukkan bahwa pertamabahan usia isteri dapat meningkatkan pembelian buah lokal. Dengan demikian juga dapat dikatakan bahwa isteri yang usianya lebih muda lebih cenderung membeli buah impor. Hal ini terjadi karena pertambahan usia berkaitan dengan pengalaman. Konsumen belajar dari pengalaman masa lalunya dan perilaku di masa depan bisa diprediksi berdasarkan perilaku masa lalunya itu (Sutisna, 2001). Puspitawati (2004) juga menjelaskan bahwa individu yang memiliki pengalaman akan memberikan persepsi yang lebih tinggi dibandingkan orang lain, karena seseorang yang berpengalaman akan semakin memiliki kemampuan dan keterampilan serta akan lebih pandai memilih sesuatu.

Lama pendidikan isteri berpengaruh signifikan positif dengan perilaku pembelian jika dilihat dari asal buah. Hasil ini berarti bahwa tingkat kepandaian isteri dalam menentukan buah yang dibeli (buah lokal atau buah impor) meningkat dengan bertambahnya jenjang pendidikan formal yang ditempuh. Pendidikan formal maupun informal dapat memengaruhi pengetahuan gizi seseorang. Dengan demikian, individu dengan tingkat pendidikan yang lebih tinggi memiliki informasi gizi yang lebih baik (Suhardjo, 2003) termasuk informasi mengenai buah yang baik (buah lokal atau buah impor) untuk dikonsumsi anggota keluarga.

Pendapatan keluarga berpengaruh signifikan negatif terhadap perilaku pembelian buah berdasarkan asalnya. Pertambahan pendapatan keluarga meningkatkan pembelian buah lokal. Keluarga yang memiliki pendapatan tinggi lebih cenderung membeli buah lokal dibandingkan dengan buah impor. Harga buah baik itu buah lokal maupun buah impor berbeda-beda bergantung pada jenis buah yang dibeli. Ada buah lokal yang dijual dengan harga yang lebih mahal, seperti apel malang. Buah yang harganya mahal lebih mudah diakses oleh keluarga dengan pendapatan yang tinggi. Soekirman (2000) mengemukakan bahwa faktor ekonomi akan mendorong keluarga untuk melakukan pemilihan sehingga konsumsi zat tertentu menjadi terbatas. Ketika keluarga memiliki sumber daya ekonomi yang terbatas maka keluarga akan mengalokasikan sumber daya tersebut untuk memenuhi kebutuhan yang menjadi prioritas utama. Oleh karenanya, penambahan pendapatan dapat membawa perbaikan pada pola konsumsi pangan dalam keluarga (Berg, 1986).

Perilaku pembelian buah juga dilihat dari frekuensi pembelian buah. Berdasarkan frekuensinya, perilaku pembelian buah dipengaruhi oleh usia isteri. Hasil ini menunjukkan bahwa pertambahan usia isteri dapat meningkatkan frekuensi pembelian buah. Menurut Sumarwan (2004), konsumen yang 
berbeda usia akan mengonsumsi produk dan jasa yang berbeda. Perbedaan usia juga akan mengakibatkan perbedaan selera dan kesukaan terhadap merek. Pertambahan usia dapat meningkatkan kebutuhan gizi dan juga berdampak pada meningkatnya frekuensi pembelian dan konsumsi. Demikian juga dengan buah, pertambahan usia berdampak pada meningkatnya perilaku pembelian dan konsumsi buah.

Aspek lain yang dilihat dalam perilaku pembelian adalah jumlah buah yang dibeli. Jumlah buah yang dibeli dipengaruhi oleh besar keluarga, usia isteri, dan lama pendidikan isteri. Besar keluarga berpengaruh signifikan positif pada jumlah buah yang dibeli. Jumlah buah yang dibeli bertambah dengan bertambahnya jumlah anggota keluarga. Hasil ini dapat terjadi karena pertambahan jumlah anggota keluarga dapat meningkatkan jumlah buah yang dibutuhkan sehingga jumlah buah yang dibeli juga akan meningkat.

Usia isteri berpengaruh positif pada perilaku pembelian yang dilihat dari jumlah buah yang dibeli. Buah yang dibeli jumlahnya meningkat dengan bertambahnya usia isteri. Jumlah buah yang dibeli juga bertambah dengan meningkatnya pendidikan isteri. Isteri yang berpendidikan tinggi memiliki pengetahuan tentang gizi yang lebih baik. Oleh karenanya, pendidikan yang tinggi dapat meningkatkan pengetahuan dan kesadaran seorang individu tentang manfaat buah bagi tubuh.

\section{SIMPULAN DAN SARAN}

Isteri yang tinggal di wilayah perdesaan dan perkotaan memiliki pengetahuan yang baik tentang buah. Pengetahuan isteri tentang buah ini berbeda signifikan antarwilayah (wilayah perdesaan dan perkotaan). Hasil penelitian menunjukkan bahwa keluarga di wilayah perkotaan mengonsumsi jenis buah yang lebih banyak (25 jenis buah) dibandingkan dengan keluarga di wilayah perdesaan (22 jenis buah). Isteri yang tinggal di wilayah perdesaan dan perkotaan memiliki perilaku pembelian buah yang berbeda signifikan jika dilihat berdasarkan keberagaman buah yang dibeli.

Perilaku pembelian buah dipengaruhi oleh karakteristik keluarga dan pengetahuan isteri. Perilaku pembelian buah berdasarkan keberagaman buah dipengaruhi oleh usia isteri, lama pendidikan isteri, dan pengetahuan isteri tentang buah. Berdasarkan asal buah (buah lokal atau buah impor), perilaku pembelian dipengaruhi oleh usia isteri, lama pendidikan isteri, dan pendapatan keluarga. Usia isteri juga berpengaruh signifikan pada perilaku pembelian yang dilihat dari frekuensi pembelian buah dan jumlah buah yang dibeli. Selain usia isteri, jumlah buah yang dibeli dipengaruhi oleh besar keluarga dan lama pendidikan.

Berdasarkan hasil, penelitian ini menyarankan perlu adanya peningkatan pengetahuan isteri melalui kegiatan penyuluhan. Penyuluhan yang diberikan adalah penyuluhan tentang pentingnya buah bagi tubuh, cara pemilihan buah yang berkualitas, serta frekuensi dan jumlah buah yang harus dikonsumsi.

\section{DAFTAR PUSTAKA}

[BPS] Badan Pusat Statistik. (2009). Jumlah Penduduk Miskin di Perkotaan Jawa Barat. Jakarta: BPS.

(2010). Jumlah

Penduduk Indonesia. Jakarta: BPS.

Berg, A. (1986). Peranan Gizi dalam Pembangunan Nasional. Jakarta: Rajawali.

Engel, J. F., Blackwell, R. D., \& Miniard, P. W. (1994). Perilaku Konsumen. Jilid ke-1. Jakarta: Binarupa Aksara.

Hardinsyah, Briawan, D., Retnaningsih, Herawati, T., \& Wijaya, R. (2002). Analisis Kebutuhan konsumsi Pangan. Di dalam: Modul Ketahanan Pangan. Jakarta: Departemen Pertanian.

Kotler, P. (2002). Manajemen Pemasaran. Jilid ke-1. Molan, B., penerjemah. Jakarta: Prenhalindo.

Papalia, D. E., Olds, S. W., \& Feldman, R. D. (2008). Human Development (Psikologi Perkembangan). Jakarta: Kencana. Terjemahan dari: Human Development.

Prasatya, R. (1998). Faktor-faktor yang berhubungan dengan preferensi dan frekuensi konsumsi buah pada golongan lanjut usia di Lembaga Seni Pernafasan Satria Nusantara Bogor [skripsi]. Bogor: Fakultas Pertanian, Institut Pertanian Bogor.

Puspitawati, E. (2004). Analisis kemitraan antara PT Petani (Persero) dengan petani penangkar benih padi di Kabupaten Karawang [tesis]. Bogor: Program Pascasarjana, Institut Pertanian Bogor. 
Soekirman. (2000). IImu Gizi dan Aplikasinya untuk Keluarga dan Masyarakat. Bogor: Departemen Pendidikan nasional, Direktorat Jenderal Pendidikan Tinggi.

Suhardjo. (1989). Sosio Budaya Gizi. Bogor: Pusat Antar Universitas Pangan dan Gizi, Institut Pertanian Bogor.
(2003). Berbagai Cara Pendidikan Gizi. Jakarta: Bumi Aksara.

Sumarwan, U. (2004). Perilaku Konsumen Teori dan Penerapannya dalam Pemasaran. Jakarta: Ghalia Indonesia.

Sutisna. (2001). Perilaku Konsumen dan Komunikasi Pemasaran. Bandung: PT Remaja Rosdakarya Bandung. 